\title{
A Novel Method to Develop Paste Formulation of Trichoderma harzianum
}

\author{
S. Balakrishnan*, S. Parthasarathy, A. Kamalakannan, \\ K. SenthilKuppusamy and C. Gopalakrishnan
}

\begin{abstract}
Department of Plant Pathology, Center for Plant Protection Studies, Tamil Nadu Agricultural University, Coimbatore- 641003, Tamil Nadu, India

*Corresponding author
\end{abstract}

\begin{tabular}{|c|c|}
\hline & A B S T R A C T \\
\hline & \multirow{8}{*}{$\begin{array}{l}\text { Biological control of diseases has been practiced as an alternative to control of plant } \\
\text { disease using fungicides. Trichoderma spp. is the most widely exploited antagonistic fungi } \\
\text { for the management of plant diseases world-wide. Though the biological control of plant } \\
\text { diseases using Trichoderma spp. has been impressive and consistence under in vitro } \\
\text { conditions, numbers of reports indicate wide variations in the disease control efficiency } \\
\text { under field conditions. Formulation plays a significant role in determining the final } \\
\text { efficacy of biocontrol agents. Several reports have emphasized the development of suitable } \\
\text { formulations for the management of various plant diseases. The present study was } \\
\text { proposed to develop a formulation of } T \text {. harzianum suitable for application through drip } \\
\text { irrigation with longer shelf life. Among the } 8 \text { media tested, medium }-\mathrm{M}_{3} \text { has recorded the } \\
\text { maximum mycelial dry weight of } 654 \mathrm{mg} \text {. The highest population }\left(11.6 \times 10^{10} \mathrm{cfu} / \mathrm{g} \text { ) was }\right. \\
\text { recorded in the fresh formulation containing } 10 \text { per cent starch }+ \text { copper sulphate } 20 \text { ppm } \\
\text { at pH } 4 \text {. Starch } 10 \text { per cent and copper sulphate } 20 \text { ppm adjusted to pH } 4 \text { has recorded } \\
\text { significantly higher population even after } 120 \text { days of storage. }\end{array}$} \\
\hline & \\
\hline & \\
\hline $\begin{array}{l}\text { Formulation, } \\
\text { Starch, Trich } \\
\text { harzianum. }\end{array}$ & \\
\hline Article Info & \\
\hline & \\
\hline & \\
\hline & \\
\hline
\end{tabular}

\section{Introduction}

The use of antagonistic micro-organisms for the control of various crop diseases has attracted considerable interest in recent years owing to the problems associated with largescale use of synthetic chemical pesticides. Many researchers have demonstrated the potential of Trichoderma spp. in control of damping-off diseases of crop plants caused by Pythium sp. Species of genus Trichoderma are well documented fungal biological control agent (Chet et al., 1981; Kleifield and Chet, 1992). Trichoderma based biocontrol agents possess better ability to promote plant growth and soil remediation activity compared to their counter parts. Trichoderma spp. have gained wide acceptance as effective biocontrol agents against several plant pathogens. The use of antagonistic microorganisms for the control of various crop diseases has attracted considerable interest in recent years owing to the problems associated with large-scale use of synthetic chemical pesticides. Many researchers have demonstrated the potential of Trichoderma spp. in control of damping-off diseases of crop plants caused by Pythium sp.(Le et al., 2003), Macrophomina phaseolina (Khan and Gupta 1998) and Rhizoctonia solani (Lewis et al.,1998). T. viride, T. harzianum and $T$. virens are being successfully used for the 
control of some of the dreaded diseases like damping off, collar rots and wilts of horticultural crops.

Development of feasible and efficient delivery systems for the application of appropriate micro-organisms to the ecosystem is an important component of biocontrol technology (Lewis et al., 1998). The formulation of microbial biomass represents a critical step advance in the commercial development of prospective biological control products. Several commercial formulations of Trichoderma are available in the market. The common formulations of Trichoderma spp. include dusts, pyrex/biomass, alginate pellets kaolin/starch/cellulose granules and extruded granules (Hebbar 1997; Lewis et al., 1998). Trichoderma spp. is being extensively marketed as talc-based powder formulation (Nakkeeran et al., 2002). The problems associated with talc-based powder formulations include dehydration and poor shelf life and loss in viability of propagules beyond three months of storage (Mukhopadhyay, 1994), which affects efficiency and marketability of the formulation (Singh et al., 2000). Although many formulations for soil incorporation are in the market, not enough work has been carried out to develop a formulation available for application through drip irrigation. Effective control of soil-borne pathogens by biocontrol agents has been widely demonstrated (Singh, 2010). Trichoderma formulations as conidia or chlamydospore have restricted gradients of dispersion and reproduction in soils. The germination of conidia or chlamydospore is vulnerable to soil fungistasis (Xu et al., 2004; Pan et al., 2006). The introduced Trichoderma spores can lyse before germination, and growth of germinating spores cannot occur due to nonavailability of continuous nutrient supply. This greatly limits the use of Trichoderma spores in controlling soil-borne diseases
(Papavizas, 1985; Hoitink and Boehm, 1999). Food supplements added to soil can maintain Trichoderma in a viable state and achieve a better biocontrol efficacy It has been demonstrated that the development of liquid formulations of bio control agents in general has several advantages including high colony forming units, longer shelf life, zero contamination, ability to with stand environmental stresses and increased field efficiency over the conventional talc based formulation. More ever when the talc based formulations are applied for the management of diseases of horticultural and plantation crops through micro irrigation techniques, blockage of nozzles often makes application laborious and cumbersome. Keeping these things in mind, the present study was proposed to develop a formulation of T.harzianum suitable for application through seed treatment and drip irrigation with longer shelf life.

\section{Materials and Methods}

\section{Collection of T.harzianum}

All the laboratory experiments were conducted at the Department of Plant Pathology, Tamil Nadu Agricultural University, Coimbatore. The culture of $T$. harzianum was obtained from the National Bureau of Agriculturally important Insects (ICAR), Hebbal, and Bengaluru. The $T$. harzianum was further sub cultured on Potato Dextrose Agar (PDA). The cultures were maintained under refrigerated condition $\left(4^{\circ} \mathrm{C}\right)$ and used periodically for preparing different formulations.

\section{Standardization of suitable liquid medium for the growth of $T$. harzianum}

Effect of eight different amendments of molasses based broth (Semi defined balanced medium) on the mycelial dry weight of 
T. harzianum was studied and the composition of eight different media were used The ingredients of urea, potassium monophosphate, magnesium sulfate, sodium citrate, sucrose were used for development of T. harzianum growth media (Table 1). From each medium $100 \mathrm{ml}$ was transferred to 250 $\mathrm{ml}$ glass jar and sterilized at $121^{\circ} \mathrm{C}$. The jars were transferred to laminar air flow chamber after cooling. Mycelial discs $(5 \mathrm{~mm})$ from actively growing tips of 7 days old $T$. harzianum cultures were aseptically transferred to glass jars. The glass jars were loosely sealed with lids and incubated at laboratory condition $\left(28 \pm 2^{\circ} \mathrm{C}\right)$ for seven days. After 7 days, the mycelial mats were collected and placed on funnel covered with Whatman No. 40 filter paper to drain out filtrates and the mycelial mats were oven dried at $85 \pm 2^{\circ} \mathrm{C}$ for 16 hours. The mats were weighed in electronic balance and recorded.

\section{Development of paste formulations}

In order to find out suitable paste formulation of $T$. harzianum which can sustain viability of conidia and chlamydospores for longer period, the present experiment was conducted using three levels of food base in the form starch viz., 5.0, 7.5 and 10 per cent and 3 levels of copper sulphate viz., 20, 40 and 60 ppm and two levels of $\mathrm{pH} v i z ., 3.0$, and 4.0 were tested for their effect on prolonging the viability of $T$. harzianum propagules.

Biomass of T. harzianum obtained from 7days old culture grown on semi defined balanced medium (SDBM) medium No - 3 was concentrated 3 - 4 fold after harvest by filtration through a sieve with a pore size of No.100 $\mu \mathrm{m}$ and mixed thoroughly in different combination of starch, copper sulphate and $\mathrm{pH}$ and stored in $250 \mathrm{ml}$ glass jar. The amount of dry substance in the concentrate was approximately at 5 per cent $(w / w)$. The viability of $T$. harzianum propagules in the formulations were tested at monthly interval up to 120 days and expressed as colony forming unit/gm of formulations.

Analyzing the survival of T.harzianum propagules in the developed formulation

One $\mathrm{g}$ of formulation was taken and dissolved in $10 \mathrm{ml}$ of sterile water and subsequent dilutions were made up to $10^{10}$. One $\mathrm{ml}$ from $10^{10}$ dilution was plated on sterile petriplates containing PDA and incubated for $48 \mathrm{hrs}$ under laboratory conditions. The colonies were counted in each treatment and recorded as cfu/g of formulation.

\section{Results and Discussion}

Effect of molasses based media on the mycelial dry weight of $T$. harzianum

Effect of different amendments in molasses based media on the mycelial dry weight of $T$. harzianum was studied and the results are presented in Table 2. Among the 8 media tested, medium $-\mathrm{M}_{3}$ has recorded the maximum mycelial dry weight of $654 \mathrm{mg}$ followed by medium - $M_{1}$ with $631 \mathrm{mg}$. However medium $\mathrm{M}_{3}$ and $\mathrm{M}_{1}$ were statistically on par with each other. Medium $\mathrm{M}_{5}$ has recorded the lowest mycelial dry weight of $50 \mathrm{mg}$.

\section{Effect of paste formulation amended with copper sulphate at $20 \mathrm{ppm}$}

The effect of different concentration of starch viz., 5, 7.5 and 10 per cent on the viability of T. harzianum was studied. Two levels of $\mathrm{pH}$ i.e. 3 and 4 were also studied for their effect on the viability of $T$. harzianum and the results are furnished in Table 3. All the six treatments have recorded higher colony forming unit immediately after formulation. However, the population started to decline after 30 days of storage under laboratory 
conditions. The highest population of $11.6 \times 10^{10} \mathrm{cfu} / \mathrm{g}$ was recorded in the fresh formulation containing 10 per cent starch + copper sulphate $20 \mathrm{ppm}$ at $\mathrm{pH}$ 4. The lowest population of $9.0 \times 10^{10} \mathrm{cfu} / \mathrm{g}$ was recorded in the fresh formulation containing starch 7.5 per cent + copper sulphate at $20 \mathrm{ppm}$ at $\mathrm{pH} 4$ as well as pH 3.

After 90 days of storage at laboratory conditions paste formulation adjusted to $\mathrm{pH} 3$ recorded zero population. However starch 10 per cent and copper sulphate 20 ppm adjusted to $\mathrm{pH} 4$ has recorded significantly higher population $\left(9.3 \times 10^{10} \mathrm{cfu} / \mathrm{g}\right) 90$ days after preparation. The same formulation has retained significantly higher population (6.6 $\times 10^{10} \mathrm{cfu} / \mathrm{g}$ ) even after 120 days of storage. All other combinations recorded zero population 120 days after storage.

\section{Effect of paste formulation amended in with copper sulphate at 40 ppm}

The highest popuation of $T$. harzianum $\left(10 \times 10^{10} \mathrm{cfu} / \mathrm{g}\right)$ was recorded in freshly prepared formulation containing starch 7.5 per cent and copper sulphate at $40 \mathrm{ppm}$ at $\mathrm{pH}$ 4 and formulation containing starch 10 per cent + copper sulphate $40 \mathrm{ppm}$ at $\mathrm{pH}$ 3.The fresh product containing at $\mathrm{pH} 3$ has recorded the lowest population of T. harzianum $(6 \times$ $\left.10^{10} \mathrm{cfu} / \mathrm{g}\right)$. In all the treatments the population has started to decline after words.

Three combinations of paste formulation at pH 3 were not able to sustain the viability $T$. harzianum after 60 days of storage. However starch 10 per cent and copper sulphate 40 ppm combination at $\mathrm{pH} 4$ sustained a population of $4.66 \times 10^{10} \mathrm{cfu} / \mathrm{g}$ after 90 days of storage.

After 120 days of storage also the same treatment alone maintained a population of $1.3 \times 10^{10} \mathrm{cfu} / \mathrm{g}$. All other treatments last the viability after 120 days of storage (Table 4).
Effect of paste formulation amended in with copper sulphate at $60 \mathrm{ppm}$

The concentration of copper sulphate was maintained at $60 \mathrm{ppm}$, the population of $T$. harzianum in the fresh product ranged from $2 \times 10^{10} \mathrm{cfu} / \mathrm{g}$ (starch $7.5 \%+\mathrm{pH}$ at $3+$ copper sulphate at $60 \mathrm{ppm})$ to $10.33 \times 10^{10} \mathrm{cfu} / \mathrm{g}$ (starch at $10 \%+\mathrm{pH}$ at $4+$ copper sulphate at $60 \mathrm{ppm})$. Three combination of paste formulation adjusted to $\mathrm{pH} 3$ recorded zero population of $T$. harzianum after 60 days of storage. All the treatments have failed to maintain the viability of $T$. harzianum propagules after 120 days of storage (Table 5).

Biological control of diseases has been practiced as an alternative to control of plant disease using fungicides. Trichoderma spp. is the most widely exploited antagonistic fungi for the management of plant diseases worldwide. Though biological control of plant diseases using Trichoderma spp. has been impressive and consistence under in vitro conditions, number of reports indicate wide variations in the disease control efficiency under field conditions, Although external factors such as temperature, rainfall and nature of plant leaf surface may influence the efficiency of Trichderma spp., nature of formulations and method of delivery are the two critical factors that influence the performance of Trichoderma spp. in vivo. Formulation plays a significant role in determining the final efficacy of biocontrol agents. Several reports have emphasized the importance of development of suitable formulations for the management of various plant diseases (Fravel and Larkins, 1996; Manikandan et al., 2010). Normally biocontrol agents formulated using inert carriers have shorter shelf life than those formulated using food additives. Talc based formulations of Trichoderma spp. is being used widely for the management of plant diseases at present. 
Table.1 Composition of media used for the production of T. harzianum in liquid culture

\begin{tabular}{|c|c|c|c|}
\hline $\begin{array}{l}\text { Media } 1\left(\mathbf{M}_{\mathbf{1}}\right) \\
\text { Molasses-30g } \\
\text { Urea- } 0.5 \mathrm{~g} \\
\text { Potassium monophosphate- } \\
2.0 \mathrm{~g} \\
\text { Magnesium sulfate- } 0.2 \mathrm{~g} \\
\text { Sodium citrate- } 0.3 \mathrm{~g} \\
\text { Dist. Water - } 1 \text { litre }\end{array}$ & $\begin{array}{l}\text { Media } 2\left(\mathbf{M}_{2}\right) \\
\text { Molasses-30g } \\
\text { Potassium monophosphate- } 2.0 \mathrm{~g} \\
\text { Magnesium sulfate- } 0.2 \mathrm{~g} \\
\text { Sodium citrate- } 0.3 \mathrm{~g} \\
\text { Dist. Water }-1 \text { litre }\end{array}$ & $\begin{array}{l}\text { Media } 3\left(\mathbf{M}_{3}\right) \\
\text { Molasses- } 30 \mathrm{~g} \\
\text { Urea- } 0.5 \mathrm{~g} \\
\text { Potassium monophosphate- } \\
1.0 \mathrm{~g} \\
\text { Magnesium sulfate- } 0.2 \mathrm{~g} \\
\text { Sodium citrate- } 0.3 \mathrm{~g} \\
\text { Dist. Water }-1 \text { litre }\end{array}$ & $\begin{array}{l}\text { Media } 4\left(\mathbf{M}_{4}\right) \\
\text { Molasses-30g } \\
\text { Potassium monophosphate- } \\
2.0 \mathrm{~g} \\
\text { Magnesium sulfate- } 0.2 \mathrm{~g} \\
\text { Dist. Water - } 1 \text { litre }\end{array}$ \\
\hline $\begin{array}{l}\text { Media } \mathbf{5}\left(\mathbf{M}_{\mathbf{5}}\right) \\
\text { Molasses-30g } \\
\text { Potassium monophosphate- } \\
2.0 \mathrm{~g} \\
\text { Magnesium sulfate- } 0.2 \mathrm{~g} \\
\text { Calcium carbonate- } 0.1 \mathrm{~g} \\
\text { Dist. Water - } 1 \text { litre }\end{array}$ & $\begin{array}{l}\text { Media } 6\left(\mathbf{M}_{\mathbf{6}}\right) \\
\text { Molasses-30g } \\
\text { Urea- } 0.5 \mathrm{~g} \\
\text { Potassium monophosphate- } 2.0 \mathrm{~g} \\
\text { Magnesium sulfate- } 0.2 \mathrm{~g} \\
\text { Calcium carbonate- } 0.1 \mathrm{~g} \\
\text { Dist. Water }-1 \text { litre }\end{array}$ & $\begin{array}{l}\text { Media } 7\left(\mathbf{M}_{7}\right) \\
\text { Molasses-30g } \\
\text { Potassium monophosphate- } \\
2.0 \mathrm{~g} \\
\text { Magnesium sulfate- } 0.2 \mathrm{~g} \\
\text { Sodium citrate- } 0.3 \mathrm{~g} \\
\text { Calcium carbonate- } 0.1 \mathrm{~g} \\
\text { Ammonium sulfate- } 1.1 \mathrm{~g} \\
\text { Sucrose- } 10 \mathrm{~g} \\
\text { Dist. Water }-1 \text { litre }\end{array}$ & $\begin{array}{l}\text { Media } 8\left(\mathbf{M}_{\mathbf{8}}\right) \\
\text { Molasses-30g } \\
\text { Potassium monophosphate- } \\
2.0 \mathrm{~g} \\
\text { Magnesium sulfate- } 0.2 \mathrm{~g} \\
\text { Ammonium sulfate- } 1.1 \mathrm{~g} \\
\text { Sucrose-10g } \\
\text { Dist. Water - } 1 \text { litre }\end{array}$ \\
\hline
\end{tabular}

Table.2 Effect of different amendments in molasses based media on the mycelial dry weight of T. harzianum

\begin{tabular}{|c|c|c|}
\hline S.No. & Media & Mycelial dry weight of T. harzianum (mg) \\
\hline 1. & $\mathrm{M}_{1}$ & $631.000^{\mathrm{a}}$ \\
\hline 2. & $\mathrm{M}_{2}$ & $109.333^{\mathrm{c}}$ \\
\hline 3. & $\mathrm{M}_{3}$ & $654.000^{\mathrm{a}}$ \\
\hline 4. & $\mathrm{M}_{4}$ & $124.000^{\mathrm{c}}$ \\
\hline 5. & $\mathrm{M}_{5}$ & $50.000^{\mathrm{c}}$ \\
\hline 6. & $\mathrm{M}_{6}$ & $348.333^{\mathrm{b}}$ \\
\hline 7. & $\mathrm{M}_{7}$ & $191.667^{\mathrm{bc}}$ \\
\hline 8. & $\mathrm{M}_{8}$ & $217.333^{\mathrm{bc}}$ \\
\hline
\end{tabular}

Values are means of 3 replications. In a column, means followed by common letters are not significantly different at the $5 \%$ level by DMRT. 
Table.3 Effect of paste formulation of T. harzianum amended with copper sulphate $\left(\mathrm{CuSO}_{4}\right)$ at $20 \mathrm{ppm}$

\begin{tabular}{|c|c|c|c|c|c|c|}
\hline \multirow{2}{*}{ S.No. } & \multirow{2}{*}{ Treatments } & \multicolumn{5}{|c|}{ Population of $T$. harzianum in $10^{10} \mathrm{cfu} / \mathrm{g}$} \\
\hline & & $0^{\text {th }}$ day & $30^{\text {th }}$ day & $60^{\text {th }}$ day & $90^{\text {th }}$ day & $120^{\text {th }}$ day \\
\hline 1. & $\mathrm{~T}_{1}-\left(\right.$ Starch $\left.5 \%+\mathrm{pH} 4+\mathrm{CuSO}_{4} 20 \mathrm{ppm}\right)$ & 10.00 & 3.00 & 1.66 & 0.33 & 0.00 \\
\hline 2. & $\mathrm{~T}_{2}-\left(\operatorname{Starch} 7.5 \%+\mathrm{pH} 4+\mathrm{CuSO}_{4} 20 \mathrm{ppm}\right)$ & 9.00 & 8.60 & 5.30 & 3.00 & 0.66 \\
\hline 3. & $\mathrm{~T}_{3}-\left(\operatorname{Starch} 10 \%+\mathrm{pH} 4+\mathrm{CuSO}_{4} 20 \mathrm{ppm}\right)$ & 11.60 & 11.30 & 10.00 & 9.30 & 6.66 \\
\hline 4. & $\mathrm{~T}_{4}-\left(\operatorname{Starch} 5 \%+\mathrm{pH} 3+\mathrm{CuSO}_{4} 20 \mathrm{ppm}\right)$ & 10.00 & 9.60 & 00.00 & 0.00 & 0.00 \\
\hline 5. & $\mathrm{~T}_{5}-\left(\operatorname{Starch} 7.5 \%+\mathrm{pH} 3+\mathrm{CuSO}_{4} 20 \mathrm{ppm}\right)$ & 9.00 & 10.30 & 00.00 & 0.00 & 0.00 \\
\hline 6. & $\mathrm{~T}_{6}-\left(\mathrm{Starch} 10 \%+\mathrm{pH} 3+\mathrm{CuSO}_{4} 20 \mathrm{ppm}\right)$ & 9.60 & 11.00 & 3.30 & 0.00 & 0.00 \\
\hline
\end{tabular}

Values are means of 3 replications.

Table.4 Effect of paste formulation of $T$. harzianum amended with copper sulphate $\left(\mathrm{CuSO}_{4}\right)$ at $40 \mathrm{ppm}$

\begin{tabular}{|c|c|c|c|c|c|c|}
\hline \multirow[t]{2}{*}{ S.No. } & \multirow[t]{2}{*}{ Treatments } & \multicolumn{5}{|c|}{ Population of $T$. harzianum in $10^{10} \mathrm{cfu} / \mathrm{g}$} \\
\hline & & $0^{\text {th }}$ day & $30^{\text {th }}$ day & $60^{\text {th }}$ day & $90^{\text {th }}$ day & $120^{\text {th }}$ day \\
\hline 1. & $\mathrm{~T}_{1}-\left(\operatorname{Starch} 5 \%+\mathrm{pH} 4+\mathrm{CuSO}_{4} 40 \mathrm{ppm}\right)$ & 8.00 & 4.00 & 0.60 & 0.00 & 0.00 \\
\hline 2. & $\mathrm{~T}_{2}-\left(\mathrm{Starch} 7.5 \%+\mathrm{pH} 4+\mathrm{CuSO}_{4} 40 \mathrm{ppm}\right)$ & 10.00 & 4.33 & 3.33 & 1.00 & 0.00 \\
\hline 3. & $\mathrm{~T}_{3}-\left(\right.$ Starch $\left.10 \%+\mathrm{pH} 4+\mathrm{CuSO}_{4} 40 \mathrm{ppm}\right)$ & 9.30 & 5.66 & 5.66 & 4.66 & 1.30 \\
\hline 4. & $\mathrm{~T}_{4}-\left(\operatorname{Starch} 5 \%+\mathrm{pH} 3+\mathrm{CuSO}_{4} 40 \mathrm{ppm}\right)$ & 9.00 & 4.66 & 0.00 & 0.00 & 0.00 \\
\hline 5. & $\mathrm{~T}_{5}-\left(\operatorname{Starch} 7.5 \%+\mathrm{pH} 3+\mathrm{CuSO}_{4} 40 \mathrm{ppm}\right)$ & 6.00 & 5.33 & 0.00 & 0.00 & 0.00 \\
\hline 6. & $\mathrm{~T}_{6}-\left(\right.$ Starch $\left.10 \%+\mathrm{pH} 3+\mathrm{CuSO}_{4} 40 \mathrm{ppm}\right)$ & 10.00 & 5.66 & 0.00 & 0.00 & 0.00 \\
\hline
\end{tabular}

Values are means of 3 replications.

Table.5 Effect of paste formulation of $T$. harzianum amended with copper sulphate $\left(\mathrm{CuSO}_{4}\right)$ at $60 \mathrm{ppm}$

\begin{tabular}{|c|c|c|c|c|c|c|}
\hline \multirow[b]{2}{*}{ S. No. } & \multirow[b]{2}{*}{ Treatments } & \multicolumn{5}{|c|}{ Population of $T$. harzianum in $10^{10} \mathrm{cfu} / \mathrm{g}$} \\
\hline & & $0^{\text {th }}$ day & $30^{\text {th }}$ day & $60^{\text {th }}$ day & $90^{\text {th }}$ day & $120^{\text {th }}$ day \\
\hline 1. & $\mathrm{~T}_{1}-\left(\operatorname{Starch} 5 \%+\mathrm{pH} 4+\mathrm{CuSO}_{4} 60 \mathrm{ppm}\right)$ & 9.60 & 6.00 & 1.00 & 0.00 & 0.00 \\
\hline 2. & $\mathrm{~T}_{2}-\left(\operatorname{Starch} 7.5 \%+\mathrm{pH} 4+\mathrm{CuSO}_{4} 60 \mathrm{ppm}\right)$ & 9.66 & 3.33 & 0.00 & 0.00 & 0.00 \\
\hline 3. & $\mathrm{~T}_{3}-\left(\mathrm{Starch} 10 \%+\mathrm{pH} 4+\mathrm{CuSO}_{4} 60 \mathrm{ppm}\right)$ & 10.33 & 4.00 & 2.66 & 1.00 & 0.00 \\
\hline 4. & $\mathrm{~T}_{4}-\left(\operatorname{Starch} 5 \%+\mathrm{pH} 3+\mathrm{CuSO}_{4} 60 \mathrm{ppm}\right)$ & 8.33 & 2.66 & 0.00 & 0.00 & 0.00 \\
\hline 5. & $\mathrm{~T}_{5}-\left(\operatorname{Starch} 7.5 \%+\mathrm{pH} 3+\mathrm{CuSO}_{4} 60 \mathrm{ppm}\right)$ & 2.00 & 2.00 & 0.00 & 0.00 & 0.00 \\
\hline 6. & $\mathrm{~T}_{6}-\left(\operatorname{Starch} 10 \%+\mathrm{pH} 3+\mathrm{CuSO}_{4} 60 \mathrm{ppm}\right)$ & 9.00 & 3.33 & 0.00 & 0.00 & 0.00 \\
\hline
\end{tabular}


However, blocking of nozzles when applied through sprayers and drip systems, bulkiness and allergy related problems warrant development of novel formulations of Trichoderma spp. to meet today's changing agricultural scenario.

Among the 8 molasses based media tested for supporting the mycelial growth of $T$. harzianum, $\mathrm{M}_{3}$ medium was found to be superior followed by $\mathrm{M}_{1}$ medium. However wide variations were observed among the 8 media tested. In addition to molasses as a carbon source, addition of other ingredients like urea $(0.5 \mathrm{~g})$, potassium monophosphate (1-2 g) and traces of magnesium sulphate and sodium citrate were found to be essential for mycelial growth of $T$. harzianumin vitro. Mass multiplying biocontrol agents using optimum growth conditions is very important, since it plays a vital role in sustaining the viability in formulated product. Substances required to sustain culture viability during storage can be added not only to harvested biomass but also to the fermentation broth at the outset of inoculum production (Kolombet et al., 2008). $\mathrm{M}_{3}$ - medium which best supported the mycelial growth of $T$. harzianum was selected and different paste formulations were prepared from the biomass cultivated using the above medium. In the present study, using this formulation, initial population of $11.60 \times 10^{10} \mathrm{cfu} / \mathrm{g}$ was obtained which gradually decreased to $11.3,10,9.3$ and $6.7 \times 10^{10} \mathrm{cfu} / \mathrm{g}$ after $30,60,90$ and 120 days of storage under laboratory condition. In other combinations though initial population was comparable with earlier combination, significant reduction in population was observed after 60 days of storage. Among two levels $\mathrm{pH}$ tested, $\mathrm{pH} 4$ was found to be optimum in reducing the metabolic activity of T. harzianum while retaining the viability of propagules. At $\mathrm{pH} 3$, most of the propagules of $T$. harzianum lost the viability after 60 days of storage under laboratory conditions. This may be due to the fact that Trichoderma may produce different types of spores, suchas chlamydospores and conidia at different $\mathrm{pH}$ levels. Usually the mycelial form will not grow and tolerate acidification process resulting in proliferation of spores in the formulation. The finding is in agreement with the results of Kolombet et al., (2008). They reported that $T$. asperellum retained the viability for more than 4 months when stored at $30^{\circ} \mathrm{C}$ at $\mathrm{pH} 4$. However, the viability was lost when the $\mathrm{pH}$ of paste formulation of $T$. asperellum was maintained at $\mathrm{pH} 3$. Copper ions operate as an enzymatic inhibitor, primarily blocking cyto chrome activity (Russel et al., 1997). Copper sulphate at more than 0.01 percent concentration can have a fungicidal effect. However in small amounts a respiratory shock occurs in cell resulting in the slowdown of cell development, but not in the loss of cell viability. We have observed more number of chlamydospores in paste formulation containing $20 \mathrm{ppm}$ of copper sulphate than in formulations containing 40 and $60 \mathrm{ppm}$ of copper sulphate. When copper sulphate was added in the formulation of $T$. asperellum, the mycelium completely lysed while chlamydospore and conidia had been produced. The paste formulation containing starch10 per cent + copper sulphate at $20 \mathrm{ppm}$ with $\mathrm{pH}$ of 3 supported the production of more chlamydospore meanwhile $60 \mathrm{ppm}$ copper sulphate supported proliferation of conidia (Kolombet et al., 2008).

Shelf life of the formulated product of biocontrol agents plays a significant role in successful marketing. In general, antagonists multiplied in an organic food base having longer shelf life than the inert or inorganic food bases. Shelf life of Trichoderma in coffee husk was more than 18 months. Talc, peat, lignite and kaolin based formulation of Trichoderma have a shelf life of 3-4 months. The viable propagules of Trichoderma in the talc formulation were reduced by 50 per cent 
after 120 days of storage (Sankar and Jayarajan, 1996).

In the present study, we prepared a paste formulation of $T$. harzianum mainly constituted of starch and copper sulphate. This formulation has a positive effect on the viability and persistence of conidia up to 4 month, this biological control approach is interesting from an environmental perspective, but also for the small scale production, with the added advantage that our paste formulation may bring down the cost of production to be commercially viable.

\section{References}

Chet, I., G.E. Harman and R. Baker. 1981. Trichoderma hamatum: its hyphal interactions with Rhizoctonia solani and Pythiumspp. Microb. Ecol., 7: 719-725.

Fravel, D.R. and R.P. Larkins. 1996. Availabity and application of biocontrol products. In: Biological and Cultural Test for Control of Plant Diseases. (Ed. Canaday, C.D.) APS Press. St. Paul, USA, pp. 1-7.

Hebbar, K.P., J.A. Lewis, S.M. Poch and R.D. Lumsden. 1997. Fermentation and formulation of mycoherbicidal strains of Fusarium oxysporum. (Abstr.). Phytopathol., 86: 58.

Hoitink, A.J. and M.J. Boehm. 1999. Biocontrol within the context of soil microbial communities: a substratedependent phenomenon. Аnnu. Rev. Phytopathol., 37: 427-446.

Kleifeld, O. and I. Chet. 1992. Trichoderma harzianum - interaction with plants and effect on growth response. Plant Soil., 144: 267-262.

Kolombet, L.V., S.K. Zhiglestova, N.I. Kosareva, E.V. Bystrova and K.S.D. Derbyshev Krasnova. 2008. Development of an extended shelf life, liquid formulation of the biofungicide
Trichoderma asperellum. World J. Microbial Biotechnol., 24: 123-131.

Le, H.T., L.L. Black and R.A. Sikora. 2003. Evaluation of Trichoderma spp. for biocontrol of tomato sudden caused by Pythium aphanidermatum following flooding in tropical hot season. Commun. Agric. Appl. Biol. Sci., 68: 463-474.

Lewis, J.A., R.P. Larkin and D.L. Rogers. 1998. A formulation of Trichoderma and Gliocladium to reduce damping-off caused by Rhizoctonia solani and saprophytic growth of the pathogen in soil less mix. Plant Dis., 82: 501-506.

Manikandan, R., D. Saravanakumar, L. Rajendran, T. Raguchander and R. Samiyappan. 2010. Standardization of liquid formulation of Pseudomonas fluorescens Pf1 for its efficacy against Fusarium wilt of tomato. Biol. Control., 54(2): 83-89.

Mukhopadhyay, A.N. 1994. Biocontrol of soil borne fungal plant pathogens - current status, future prospects and potential limitations. Indian Phytopathol., 47: 119126.

Nakkeeran, S., A.S. Krishnamoorthy, V. Ramamoorthy and P. Renukadevi. 2002. Microbial inoculants in plant disease control. J. Ecobiol., 14: 83-94.

Pan, W., C. Mu, X. Jiang, Y. Tian and C. Zhu. 2006. Chlamydospore and conidia of Trichoderma and soil fungistasis. Chin. J. Biol. Control., 22: 87-91.

Papavizas, G.C. 1985. Trichoderma and Gliocladium: biology, ecology, and potential for biocontrol. Annu. Rev. Phytopathol., 23: 23-54.

Russel, A.D., J.R. Furr and J.Y. Mailard. 1997. Microbial susceptibility and resistance to biocides. ASM News.,63: 481-486.

Sankar, P. and R. Jeyarajan. 1996. Biological control of sesamum root rot by seed treatment with Trichoderma spp. and 
Bacillus subtilis. Ind. J. Mycol. Pl. Pathol., 26: 147-153.

Singh, N.K. 2010. Cyamopsis tetragonoloba L. Taub. inoculated with arbuscular mycorrhiza and Pseudomonas fluorescens and treated with mustard oil cake overcome Macrophomina root-rot losses. Biol. Fertil. Soils, 46: 237-245.
Singh, R.S., S. Puneet, K.S.P. Jaspal and J. Kaur. 2000. Trichoderma based biofungicide: progress and prospects. Plant Dis. Res., 15: $155-161$.

Xu, C., M. Mo and K. Zhang. 2004. Soil fungistasis to Trichoderma spp. and its annulment. J. Nanjing Norm. Univ., 27: 77-80.

\section{How to cite this article:}

Balakrishnan, S., S. Parthasarathy, A. Kamalakannan, K. SenthilKuppusamy and Gopalakrishnan, C. 2017. A Novel Method to Develop Paste Formulation of Trichoderma harzianum. Int.J.Curr.Microbiol.App.Sci. 6(11): 3286-3293.

doi: https://doi.org/10.20546/ijcmas.2017.611.385 